\title{
FENOMENA CASHLESS SOCIETY DALAM PANDEMI COVID-19 (KAJIAN INTERAKSI SIMBOLIK PADA GENERASI MILENIAL)
}

\author{
Firman Katon ${ }^{1}$, Ulfa Yuniati ${ }^{2}$ \\ ${ }^{1,2}$ Universitas Muhammadiyah Bandung, Bandung, Indonesia
}

\begin{abstract}
ABSTRAK
Adanya resiko terinfeksi virus corona dalam bertransaksi keuangan secara langsung menjadi kekhawatiran masyarakat dalam setiap aktivitas pembelian. Sehingga masyarakat memilih menggunakan transaksi keuangan tanpa kontak dengan melakukan pembayaran melalui aplikasi dompet digital. Penggunaan aplikasi dompet digital saat pandemi Covid-19 dan adanya kebijakan di rumah saja (stay at home) mengarah kepada cashless society. Cashless society adalah sebutan yang merujuk pada masyarakat yang dalam bertransaksi, tidak lagi menggunakan uang fisik, melainkan melalui perpindahan informasi finansial secara digital. Dalam bertransaksi sehari-hari, masyarakat tidak menggunakan uang nyata, melainkan uang digital. Transaksi keuangan tanpa kontak dan jarak jauh saat pandemi tampaknya menjadi cara yang disukai untuk menyelesaikan berbagai hal. $O V O$ merupakan salah satu cara dalam bertransaksi yang aman dan juga terbebas dari virus terutama penyakit COVID-19. Penelitian ini bertujuan untuk mengetahui bagaimana motif dalam menggunakan OVO dan interaksi (termasuk mind, self, society) yang dilakukan oleh mahasiswa Universitas Muhammadiyah Bandung selama pandemi COVID-19. Jenis penelitian ini termasuk penelitian kualitatif yng menggunakan metode penelitian fenomenologi dengan pendekatan interaksi simbolik. Teknik pengumpulan data dilakukan dengan wawancara, metode observasi non-partisipan pada 15 key informant mahasiswa Universitas Muhammadiyah Bandung. Hasil penelitian menunjukan motif dalam penggunaan aplikasi OVO yaitu pada shopping dan relaxation. Interaksi yang terjadi mengacu pada konsep mind, self, society adalah generasi milenial (mahasiswa UMBandung) menggunakan transaksi OVO selama pandemi Covid-19 cenderung ke perilaku gaya hidup baru sebagai bentuk kemudahan layanan masyarakat untuk mengurangi resiko terinfeksi virus corona. Penelitian selanjutnya dapat fokus pada hubungan perilaku dan adaptasi penggunaan dompet digital di era new normal pandemic Covid19.
\end{abstract}

Kata-kata Kunci: cashless society, dompet digital, interaksi simbolik, milenial, COVID-19

\section{CASHLESS SOCIETY PHENOMENONS IN THE COVID-19 PANDEMY (STUDY OF SYMBOLIC INTERACTIONS IN MILLENNIAL GENERATION)}

\begin{abstract}
The risk of being infected by the coronavirus in direct financial transactions is a concern for the public in every purchasing activity. So that people choose to use financial transactions without contact by making payments through digital wallet applications. The use of digital wallet applications during the Covid-19 pandemic and the stay at home policy led to a cashless society. Cashless society is a term that refers to people who do not use physical money in their transactions but through digital financial information transfer. In everyday transactions, people do not use real money, but digital money. Contactless and long-distance financial transactions
\end{abstract}


during a pandemic seem to be the preferred way to get things done. OVO is a safe way to transact and is free from viruses, especially COVID-19 disease. This study aims to determine how the motives for using $O V O$ and interactions (including mind, self, society) conducted by students of the University of Muhammadiyah Bandung during the COVID-19 pandemic. This type of research includes qualitative research using phenomenological research methods with symbolic interaction approaches. Data collection techniques were carried out by interviews, non-participant observation methods on 15 key informants of Bandung Muhammadiyah University students. The results showed the motive for using the OVO application, namely shopping and relaxation. Interactions that occur refer to the concept of mind, self, society as millennial generation (UMBandung students) using OVO transactions during the Covid-19 pandemic tends to new lifestyle behaviors as a form of ease of community service to reduce the risk of coronavirus infection. Future studies can focus on the relationship of behavior and adaptation to the use of digital wallets in the new normal pandemic Covid-19 era.

Keywords: cashless society, digital wallet, symbolic interaction, millennial, COVID-19

\section{PENDAHULUAN}

Pandemi telah mengubah habit masyarakat atau perilaku masyarakat dalam bertransaksi secara nontunai dengan menggunakan dompet digital atau $e$-wallet agar mengurangi resiko terinfeksi virus corona yang menempel pada uang, kartu kredit atau tangan orang yang menyerahkan atau menerima uang tersebut. World Health Organization (WHO) mengimbau masyarakat agar dapat menerapkan contactless payment. Contactless payment dimaksudkan disini adalah mengurangi kontak dengan pembayaran tunai dengan menggunakan dompet digital atau transaksi elektronik (Anonim, 2020).

Adanya transaksi menggunakan dompet digital adalah wujud dari perkembangan teknologi. Masyarakat pun telah dikenalkan dengan gaya hidup tanpa uang tunai (cashless society) atau dikenal dengan Gerakan Non Tunai.

Cashless society adalah sebutan yang merujuk pada masyarakat yang dalam bertransaksi, tidak lagi menggunakan uang fisik, melainkan melalui perpindahan informasi finansial secara digital. Dalam bertransaksi sehari-hari, masyarakat tidak menggunakan uang nyata, melainkan uang digital (Bintarto, 2018).

Dompet digital adalah jenis akun prabayar yang dilindungi dengan kata sandi di mana pengguna dapat menyimpan uang untuk setiap transaksi online, seperti pembayaran untuk makanan, belanja barang online, dan tiket penerbangan. Dompet digital bisa di unduh secara gratis melalui smartphone setiap orang (Rosmayanti, 2019). Dompet digital telah menjadi bagian dari kehidupan sehari-hari masyarakat dimana dalam waktu 
seminggu sekitar satu hingga dua kali menggunakan pembayaran transaksi mencapai $68 \%$.

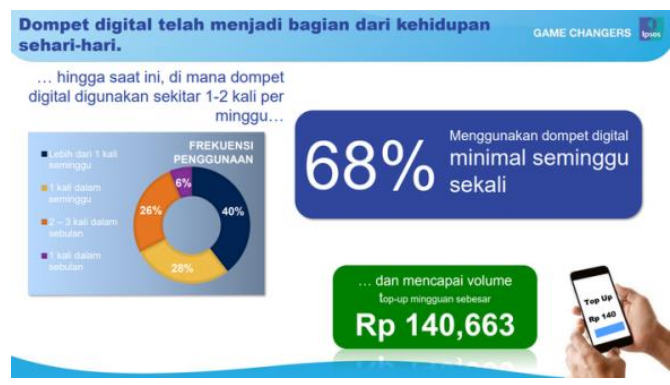

Sumber: https://nextren.grid.id(Prama, 2020)

\section{Gambar 1: Dompet Digital Menjadi Kehidupan Sehari-hari}

Adanya dompet digital seperti OVO, Gopay, Dana, Linkaja menjadikan manusia konsumtif dikarenakan mudahnya layanan transaksi melalui digital. Transaksi yang paling sering digunakan menurut hasil riset lembaga riset berbasis aplikasi, snapchart yaitu transaksi retail (28\%), pemesanan transportasi online (27\%), dan pemesanan makanan online (20\%). Sisanya, untuk transaksi e-commerce $(15 \%)$ dan pembayaran tagihan $(7 \%)$. Segmen transaksi pemesanan transportasi online dan pengiriman makanan online, data penelitian Snapcart menunjukkan posisi ovo sebagai dompet digital layanan Grab dan Grab Food menunjukkan 71\% responden yang menggunakan ovo untuk transaksi ini (sutriyanto, 2019).
Berdasarkan data di atas dapat dikatakan bahwa uang elektronik untuk transaksi harian seperti transportasi, pengiriman makanan cepat saji, dan belanja telah popular di kalangan konsumen Indonesia terutama pada kaum generasi milenial maupun generasi $\mathrm{Z}$ yang dikenal fasih menggunakan teknologi.

Bagi generasi milenial, sudah menjadi hal yang biasa berbelanja atau bertransaksi tanpa uang tunai. Mereka sudah terbiasa menggunakan alat-alat elektronik seperti kartu debit, kredit, ataupun uang elektronik (Rif'ah, 2019).

Maraknya penggunaan dompet digital di kalangan generasi milenial menjadikan ketertarikan peneliti dalam hal memanfaatkan teknologi kekinian (uang elektronik) dari motif dan interaksi. Untuk mengetahui hal tersebut peneliti menggunakan pendekatan interaksi simbolik.

Melalui kajian komunikasi interaksi simbolik, dibagi menjadi tiga konsep kritis yaitu mind, self, dan society (Ardianto, 2007:136). (1) Mind: Berfikir menurut Mead adalah suatu proses dimana individu berinteraksi dengan dirinya sendiri menggunakan simbol-simbol bermakna. Dari proses tersebut individu memilih yang mana diantara stimulus yang tertuju 
kepadanya dan ditanggapi (Irawan, 2013). Melalui konsep mind, pikiran masyarakat terhadap media sosial yang digunakan untuk aktivitas interaksi sosial dengan kehidupan saat pandemi.

(2) Self: Berkaitan dengan proses refleksi diri yang secara umumn disebut sebagai self control atau self monitoring. Melalui refleksi diri itulah menurut Mead individu mampu menyesuaikan dengan keadaan di mana mereka berada, sekaligus menyesuaikan dari makna dan efek tindakan yang mereka lakukan. (3) Society: sebuah tatanan hubungan sosial yang diciptakan, dibangun, dan dikonstruksikan oleh tiap individu ditengah masyarakat, dan tiap individu tersebut terlibat dalam perilaku yang mereka pilih secara aktif dan sukarela, yang pada akhirnya mengantarkan manusia dalam proses pengambilan peran di tengah masyarakatnya. (Nugroho, 2015).

Banyaknya dompet digital yang ada di Indonesia peneliti hanya mengambil OVO sebagai objek penelitian sedangkan subjek penelitiannya yakni mahasiswa Universitas Muhammadiyah Bandung yang termasuk ke rentang usia generasi milenial. Adapun rentang usia generasi milenial diantara tahun 1980 hingga tahun 2000. Mereka disebut generasi milenial karena merekalah generasi yang hidup di pergantian milenium (Yuswohady, 2016).

OVO adalah sebuah aplikasi smart memberikan layanan pembayaran dan transaksi secara online (OVO Cash), juga bisa berkesempatan untuk mengumpulkan poin setiap kali melakukan transaksi pembayaran melalui Ovo. Ovo cash dapat digunakan untuk berbagai macam pembayaran yang telah bekerja sama dengan ovo menjadi lebih cepat. (www.ovo id./faq). Ovo mendapatkan predikat sebagai top of mind kategori dompet digital dari masyarakat sebesar $45 \%$.

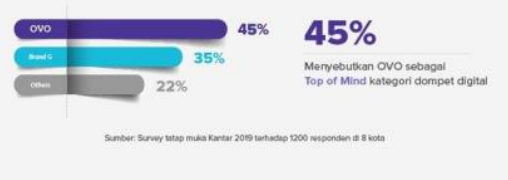

\section{Gambar 2: OVO Sebagai Top Of Mind Dompet Digital \\ Sumber: https://www.tribunnews.com}

\section{METODE PENELITIAN}

Penelitian ini menggunakan pendekatan kualitatif, dengan pendekatan fenomenologi. Fenomenologi dapat diartikan pengalaman subjektif atau pengalaman fenomenologikal. Pandangan berfikir yang menekankan pada fokus pengalaman-pengalaman subjektif 
manusia dan interpretasi dunia (Moleong, 2006).

Pemilihan informan dengan teknik purposive sampling, yaitu teknik sampling yang menggunakan kriteria terpilih oleh peneliti dalam memilih sampel. Kriteria informan yang dipilih dengan menggunakan pertimbangan tertentu yang sesuai dengan ciri-ciri spesifik yang dimilikinya (Nasution, 2006, p. 98). Penelitian ini yang menjadi sampel adalah mahasiswa Universitas Muhammadiyah Bandung. Jumlah mahasiswa Universitas Muhammadiyah Bandung yakni 780 orang dari angkatan 2016-2019.

Peneliti menggunakan rumus Slovin untuk menentukan sampel.

$$
\begin{aligned}
& n=\frac{N}{1+N(d)^{2}} \\
& \mathrm{n}=\text { jumlah sampel } \\
& \mathrm{N}=\text { jumlah populasi } \\
& \mathrm{d}=\text { tingkat presisi kesalahan }(10 \%)
\end{aligned}
$$

Berdasarkan rumus di atas maka didapatkan jumlah sampel 88 orang. Jumlah sampel 88 kemudian peneliti menentukan kriteria dari 88 tersebut untuk dijadikan sebagai sampel yang memenuhi kriteria dari peneliti. Adapun kriteria yang dijadikan sebagai sampel penelitian yaitu: (1) Informan yang usianya termasuk ke dalam generasi milenial yaitu antara tahun 1980-2000,
(2) Informan yang aktif menggunakan aplikasi OVO untuk keperluan seharihari (menggunakan transportasi online, (3) informan yang melakukan pembelian makanan dan minuman online melalui aplikasi grabfood, (4) informan yang mencari promo atau diskon.

\section{Tabel 1: Hasil Purposive Sampling}

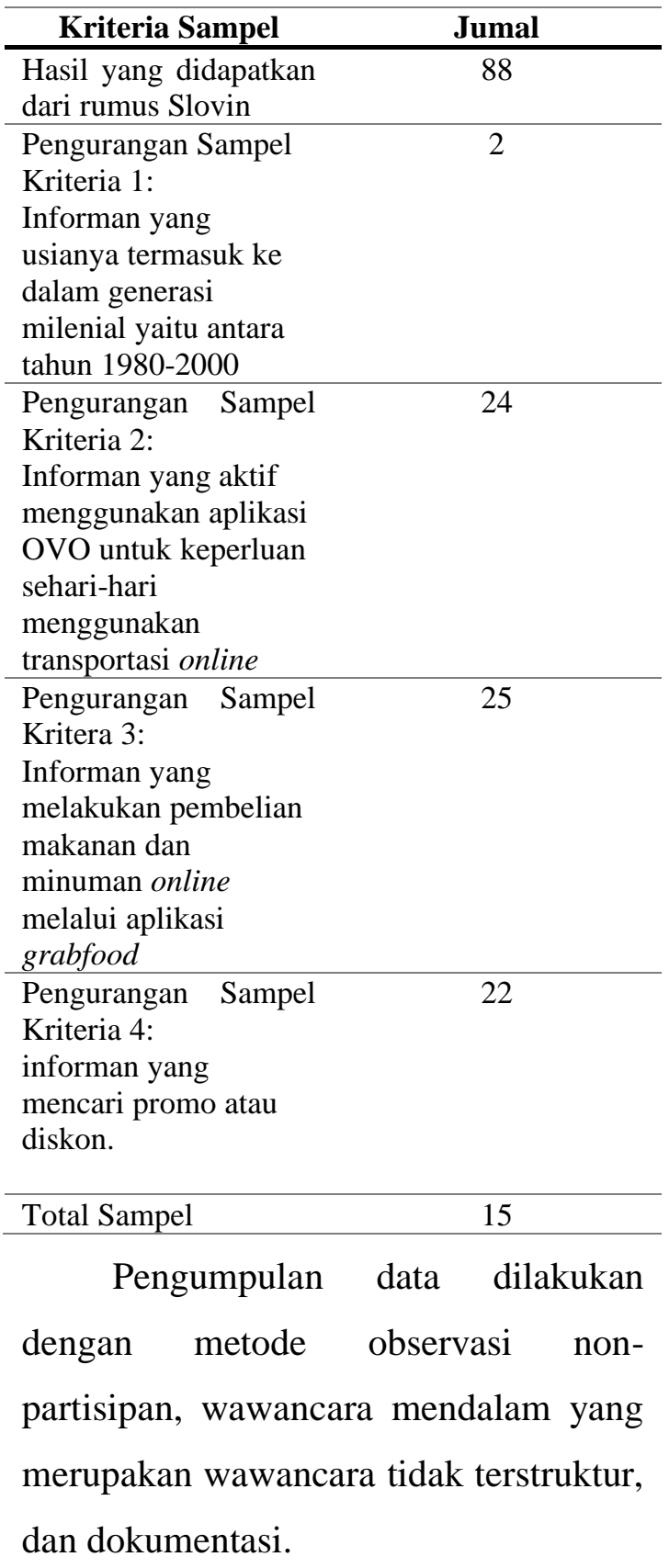


HASIL DAN PEMBAHASAN

Hasil yang ditemukan di lapangan berdasarkan wawancara dengan narasumber yakni motif dan interaksi yang dilakukan generasi milenial dalam menggunakan dompet digital OVO berbeda-beda berdasarkan faktor because motives dan in order to motive.

\section{Motif}

Berdasarkan hasil wawancara terhadap key informant maka dapat dianalisis antara hubungan konsep diri dengan motivasi penggunaan internet. Beberapa penuturan di atas sangat terlihat jelas bahwa penggunaan aplikasi dompet digital OVO berada pada motivasi shopping dan relaxation. Faktor shopping terdiri dari mendapatkan informasi tentang barang dan membeli produk yang diinginkan, sedangkan faktor relaxation terdiri dari memesan sesuatu lebih cepat, merasa lebih nyaman dan aman ketika bertransaksi, tidak merasa khawatir terhadap keuangan dan mempermudah pembayaran.

Ketika seseorang sudah mencapai tahap termotivasi, maka keadaan orang internal tersebut yang akan merangsang seseorang untuk bertindak ke arah tertentu dan menahannya untuk menjalankan aktifitas tersebut dan kemudian sampailah mereka kepada perilaku yang konsumtif. Adapun motif generasi millenial khususnya mahasiswa di Unversitas Muhammadiyah Bandung menggunakan aplikasi OVO dalam penelitian ini dipaparkan berdasarkan hasil wawancara sebagai berikut.

Tabel 2: Motif Mahasiswa UMBandung

\begin{tabular}{|c|c|}
\hline Mahasiswa & Motif Tindakan \\
\hline Ayu permata & Kadang pake ovo kadang pake \\
\hline Dewi & $\begin{array}{l}\text { gopay juga. Tergantung } \\
\text { kebutuhan }\end{array}$ \\
\hline Citra Lova & Praktis aj \\
\hline $\begin{array}{l}\text { Nanin } \\
\text { Nurhanisah }\end{array}$ & $\begin{array}{l}\text { Pake ovo karena ajakan orang, } \\
\text { kesini pun jadi suka pake } \\
\text { karena ada promo-promo jadi } \\
\text { lebih murah }\end{array}$ \\
\hline $\begin{array}{l}\text { Mia } \\
\text { Rahmawati }\end{array}$ & $\begin{array}{l}\text { Praktis pembayarannya, } \\
\text { banyak promonya. Pake ovo } \\
\text { karena keperluan sehari-hari }\end{array}$ \\
\hline $\begin{array}{l}\text { IIP Syarip } \\
\text { Hidayatullah }\end{array}$ & $\begin{array}{l}\text { Praktis untuk kemana-mana. } \\
\text { Apalagi kalau ada promo }\end{array}$ \\
\hline $\begin{array}{l}\text { Ima } \\
\text { Mukaromah }\end{array}$ & $\begin{array}{l}\text { Pake ovo karena mudah beli } \\
\text { apa aja apalagi kalau lagi } \\
\text { malas kemana-mana untuk } \\
\text { pesan makan/minum ataupun } \\
\text { mengirim barang }\end{array}$ \\
\hline $\begin{array}{l}\text { Tsabita } \\
\text { Rasyida }\end{array}$ & $\begin{array}{l}\text { Pake ovo karena keperluan } \\
\text { sehari-hari. Suka aja karena } \\
\text { mudah }\end{array}$ \\
\hline $\begin{array}{l}\text { Rika Dwi } \\
\text { Nurdiyah }\end{array}$ & $\begin{array}{l}\text { Pake ovo karena keperluan } \\
\text { sehari-hari }\end{array}$ \\
\hline $\begin{array}{l}\text { Muthiah } \\
\text { Hadiyati } \\
\text { Sabila }\end{array}$ & $\begin{array}{l}\text { Pake ovo karena keperluan } \\
\text { sehari-hari }\end{array}$ \\
\hline $\begin{array}{l}\text { Nisa Nur } \\
\text { Aeni Latifah }\end{array}$ & $\begin{array}{l}\text { Praktis, Pake ovo karena } \\
\text { keperluan sehari-hari }\end{array}$ \\
\hline $\begin{array}{l}\text { M.Dinar } \\
\text { Abdul Malik }\end{array}$ & $\begin{array}{l}\text { Dorongan atau ajakan dari } \\
\text { orang terdekat. Praktis juga sih } \\
\text { untuk pembayaran tapi } \\
\text { disesuaikan dengan kebutuhan } \\
\text { juga. Ada promo tertarik } \\
\text { menggunakannya tapi tidak } \\
\text { terlalu signifikan karena } \\
\text { tergantung kebutuhan saya. }\end{array}$ \\
\hline $\begin{array}{l}\text { Ali Musa } \\
\text { Daud }\end{array}$ & $\begin{array}{l}\text { Praktis pembayarannya untuk } \\
\text { keperluan sehari-hari. Promo } \\
\text { senang karena murah. Tapi } \\
\text { tidak terlalu signifikan sih. }\end{array}$ \\
\hline $\begin{array}{l}\text { Furi Junia } \\
\text { Defiq }\end{array}$ & $\begin{array}{lr}\text { Banyak promosinya, praktis } \\
\text { dalam } \\
\text { disesuaikan } & \begin{array}{r}\text { pembayaran, } \\
\text { dengan }\end{array}\end{array}$ \\
\hline
\end{tabular}




\begin{tabular}{ll}
\hline & $\begin{array}{l}\text { kebutuhan. Kalau lagi ada } \\
\text { promo apalagi murah }\end{array}$ \\
\hline Anita Putri & $\begin{array}{l}\text { Praktis dalam pembayaran dan } \\
\text { Meliyanti }\end{array}$ \\
& $\begin{array}{l}\text { murah kalau ada promo. } \\
\text { dibandingkan lain }\end{array}$ \\
\hline Novianti & Dorongan atau ajakan kerabat \\
Liana P & atau teman. Suka lihat promo \\
& dan pake promo yang cafenya \\
& mengikuti promo dari ovo. \\
& Kalau gak ya gak bisa dipake \\
& kode promonya. \\
\hline
\end{tabular}

Sumber: Olahan Peneliti, 2020

Berdasarkan tabel di atas bahwa peneliti menganalisis dari sisi motif mahasiswa yang termasuk generasi milenial ada 3 motif: pertama, faktor promo atau diskon atau cashback yang diberikan OVO. Motif dalam memburu promo yang dialami oleh generasi milenial dalam menggunakan aplikasi ovo pernah dialami. Beberapa diantara mereka menyatakan bahwa dalam menggunakan promo diskon ataupun cashback yang ada di aplikasi membuat pembayaran entah itu makan, minuman, berbelanja dan sebagainya menjadi lebih murah.

Di sisi lain ada mahasiswa yang berdasarkan pengalaman bahwa dalam menggunakan promo itu tidak terlalu signifikan dalam menggunakannya karena beberapa promo akan diambil jika sesuai kebutuhan. Pengalaman lainnya adalah kode promo yang diberikan ovo hanya tempat makan yang telah mengikuti event promo dari pihak ovo nya yang tersambung pada layanan transportasi online yakni Grab.

Faktor kedua, praktis dalam pembayaran. Era serba digital teknologi memudahkan kita dalam melakukan berbagai hal salah satunya ialah dalam melakukan transaksi pembayaran. Dompet digital terutama OVO memberikan pelayanan dengan kemudahan penggunanya dalam melakukan pembayaran melalui smartphone mereka. Pengguna hanya perlu terhubung dengan koneksi internet untuk menggunakan aplikasi OVO dan memiliki saldo di akun masing-masing.

Menurut mereka mengguna ovo sebagai dompet digital sangat terbantu sekali dalam melakukan pembayaran. Pengguna tidak perlu repot lagi dalam pembayaran yang dimana jumlah uang yang dikeluarkan bisa sesuai dengan tarif produk yang di inginkan juga pengguna cukup melakukan scan barcode yang sudah disediakan oleh outlet untuk melakukan pembayaran, sehingga tidak perlu ribet untuk mengeluarkan uang dalam dompet.

Faktor ketiga adalah dorongan atau ajakan. Salah satu faktor yang memengaruhi mereka dalam menggunakan aplikasi ovo ialah orang terdekat mereka bisa orang tua, kakak, ataupun teman. Motif mereka 
menggunakan ovo karena ajakan tentunya telah diberikan penjelasan dari teman, orang tua, kakak, saudara mengenai aplikasi ovo yang dimana bisa digunakan untuk melakukan pembayaran, melakukan transfer uang, serta promo menarik untuk menghemat biaya dalam melakukan transaksi layanan transportasi online ataupun memesan makanan/minuman.

Selain itu motif dari mahasiswa UMBandung berdasarkan teori fenomenologi Alfred Scutz adalah seseorang melakukan sebuah tindakan tentunya berdasarkan pada because motive dan in order to motive. Because motive adalah merujuk kepada pengalaman masa lalu mahasiswa sehingga menjadikan pengalaman tersebut sebagai salah satu alasan untuk melakukan pembayaran cashless. Berdasarkan hasil penelitian maka yang menjadi motif masa lalu mahasiswa menggunakan pembayaran cashlees adalah pemanfaatan waktu yaitu memudahkan pemesanan makanan dikarenakan sedang mengerjakan pekerjaan ataupun mager (malas gerak) dan adanya pengaruh orang lain yang memengaruhi mereka untuk menggunakan layanan OVO atau dompet digital.
Sedangkan in order to motive yang berarti tujuan yang digambarkan sebagai maksud, rencana, harapan, minat yang diinginkan mahasiswa mau menggunakan layanan dompet digital, yaitu: dengan menggunakan OVO menambah pengalaman dalam menggunakan inovasi teknologi serta menikmati adanya promo dan adanya keinginan untuk nantinya berganti ke dompet digital yang memberikan pelayanan baik dan memuaskan kebutuhan.

Berdasarkan paparan motif di atas, hal ini jika dikaji menggunakan interaksi simbolik maka akan saling berhubungan terhadap aktivitas manusia yang akan datang. Karena di dalam interaksi simbolik membahas mind, self, society.

\section{Interaksi Simbolik}

Kajian interaksi simbolik memiliki tiga konsep diantaranya mind (pikiran), self (diri), society (masyarakat). Ketiga konsep tersebut dihubungan dengan transaksi aman menggunakan ovo selama pandemi Covid-19. (1) Konsep pertama adalah mind atau pikiran; dalam teori ini pikiran merupakan proses dari kegiatan interaksi dengan diri sendiri. Hal tersebut penting karena akan menjadi bagian penting dari kehidupan manusia 
dalam hal setiap tindakan yang dilakukan. Sebelum melakukan sebuah tindakan dalam bertransaksi, pengguna aplikasi OVO, sering kali melakukan interaksi dengan dirinya sendiri. Interaksi yang terjadi dalam diri pengguna dapat dicontohkan dengan pengguna akan mempertimbangkan dan memikirkan tindakannya dalam menggunaakan aplikasi OVO dalam hal bertransaksi seperti penggunaan transportasi online, pembelian makanan, minuman dsb.

Saat situasi Pandemi COVID-19 pembentukan identitas diri mahasiswa UMBandung yang juga pada konsep mind atau pikiran dalam interaksionalisme simbolik, mempertimbangkan untuk bertransaksi mengunakan dompet digital dibandingkan dengan uang tunai. Hal ini merasa khawatir terhadap penularan COVID-19 dari transaksi secara langsung.

Namun konsep mind atau pikiran manusia tentunya memiliki dua pilihan dalam tindakannya. Ketika mereka tidak memiliki saldo dalam akun OVO atau kondisi yang tidak memungkinkan seperti tidak bisa membayar lewat OVO terpaksa menggunakan uang cash dan mengikuti standar protokol yang sudah ada yaitu dengan mencuci tangan, menyemprotkan disenfiktan ke kantong plastik (luar plastik) yang membungkus makanan.

Berikut gambaran mind generasi milenial berdasarkan hasil wawancara.

Tabel 3: Mind Generasi Milenial Selama Pandemi Covid-19

\begin{tabular}{|c|c|}
\hline Nama & $\begin{array}{l}\text { Faktor penggunaan } \\
\text { Aplikasi OVO }\end{array}$ \\
\hline $\begin{array}{l}\text { Ayu permata } \\
\text { Dewi }\end{array}$ & $\begin{array}{l}\text { Praktis dan menghindari } \\
\text { penyebaran COVID - } 19\end{array}$ \\
\hline Citra Lova & $\begin{array}{l}\text { Lebih banyak promo, dan } \\
\text { memutus rantai penyeberan } \\
\text { lewat uang }\end{array}$ \\
\hline $\begin{array}{l}\text { Nanin } \\
\text { Nurhanisah }\end{array}$ & $\begin{array}{l}\text { Lebih praktis dan } \\
\text { menghindari penulaan virus } \\
\text { COVID }-19\end{array}$ \\
\hline $\begin{array}{l}\text { Mia } \\
\text { Rahmawati }\end{array}$ & $\begin{array}{l}\text { Mengurangi } \\
\text { langsung / psyhcal discanting }\end{array}$ \\
\hline $\begin{array}{l}\text { IIP Syarip } \\
\text { Hidayatullah }\end{array}$ & 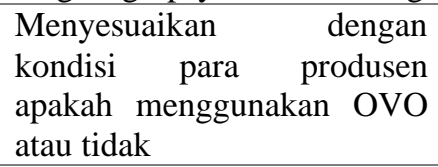 \\
\hline $\begin{array}{l}\text { Ima } \\
\text { Mukaromah }\end{array}$ & $\begin{array}{l}\text { Mengantisipasi tercegahnya } \\
\text { virus yang menular jika } \\
\text { menggunakan uang cash }\end{array}$ \\
\hline $\begin{array}{l}\text { Tsabita } \\
\text { Rasyida }\end{array}$ & $\begin{array}{l}\text { Disesuaikan dengan kondisi } \\
\text { keuangan dan juga promo } \\
\text { yang tersedia di aplikasi } \\
\text { OVO }\end{array}$ \\
\hline $\begin{array}{l}\text { Rika Dwi } \\
\text { Nurdiyah }\end{array}$ & $\begin{array}{l}\text { Menghindari penularan virus } \\
\text { corona }\end{array}$ \\
\hline $\begin{array}{l}\text { Muthiah } \\
\text { Hadiyati } \\
\text { Sabila }\end{array}$ & $\begin{array}{l}\text { Cashback dan mencegah } \\
\text { penyebaran COVID - } 19\end{array}$ \\
\hline $\begin{array}{l}\text { Nisa Nur Aeni } \\
\text { Latifah }\end{array}$ & $\begin{array}{l}\text { Lebih cepat pembayaran , } \\
\text { tidak perlu menunggu } \\
\text { kembalian dan mencegah } \\
\text { tertular COVID - } 19\end{array}$ \\
\hline $\begin{array}{l}\text { M.Dinar } \\
\text { Abdul Malik }\end{array}$ & $\begin{array}{l}\text { Menyesuaikan dengan } \\
\text { protokol kesehatan }\end{array}$ \\
\hline Ali Musa Daud & $\begin{array}{l}\text { Mencegah penularan virus } \\
\text { corona lewat uang cash }\end{array}$ \\
\hline $\begin{array}{l}\text { Furi } \\
\text { Defiq }\end{array}$ & Mencegah terpaparnya virus \\
\hline $\begin{array}{l}\text { Anita Putri } \\
\text { Meliyanti }\end{array}$ & $\begin{array}{l}\text { Menyesuaikan } r \text { dengan } \\
\text { kondisi para produsen } \\
\text { apakah menggunakan OVO } \\
\text { atau tidak }\end{array}$ \\
\hline $\begin{array}{l}\text { Novianti Liana } \\
\mathbf{P}\end{array}$ & $\begin{array}{l}\text { Menyesuaikan dengan sesuai } \\
\text { kebutuhan }\end{array}$ \\
\hline
\end{tabular}


Konsep kedua dari interaksi simbolik adalah self atau diri. Pengguna Aplikasi OVO memikirkan setiap tindakan dan sikap yang dilakukannya dalam memanfaatkan Aplikasi OVO dalam kondisi COVID-19. Pengguna OVO di kalangan mahasiswa UMBandung, sering memandang diri mereka dengan cara orang lain memandang diri mereka. Artinya bahwa sesuai dengan konsep diri yang kemudian akan menuntun pengguna aplikasi OVO membentuk konsep dirinya dalam dunia siber.

Mereka akan belajar mengenal gambaran diri mereka melalui interaksi simbolik dengan individu yang ada disekitarnya. Begitu pula dalam menggunakan aplikasi OVO, mereka dalam menggunakan dompet digital OVO akan mengenal gambaran diri mereka melalui interaksi transaksi yang dilakukan entah konsumtif yang berlebihan atau biasa saja. Dalam kondisi pandemi COVID - 19 ini pula memberikan efek yang meningkat pula terhadap kegiatan transaksi menggunakan aplikasi OVO. Beberapa diantaranya beranggapan bahwa ketika menggunakan Aplikasi OVO lebih aman ketimbang uang tunai karena kecil kemungkinannya tertular virus. Hal tersebut menjadi pembentukan gambaran bahwa mereka dalam hal kehawatiran, kewaspadaan terutama terhadap penyakit Covid-19 baik itu meningkat daripada atau biasa saja.

Konsep ketiga adalah society atau masyarakat. Pada teori interaksionalisme simbolik, masyarakat terdiri atas perilaku yang saling bekerjasama diantara para anggotanya. Dalam fenomena ini, pengguna dompet digital OVO oleh mahasiswa UMBandung merupakan bagian masyarakat yang ada dalam dunia online. interaksi yang diberikan antara kosumen (Mahasiswa UMBandung) dan produsen (layanan jasa dan barang) berupa transaksi perdagangan yang dimaknai dalam kondisi pandemi COVID-19 sebagai dukungan atas pemutusan rantai penyebaran COVID19. Keadaan pandemi COVID-19 ini mempengaruhi antara konsumen dan produsen, menggambarkan sebuah konsep dalam teori ini. Peran aplikasi OVO dalam membentuk identitas diri Mahasiswa UMBandung adalah sebagai wadah atau perangkat untuk memfasilitasi mahasiswa UMBandung dalam mengkonstruksi diri dalam bertransaksi kepada produsen dengan mudah, dapat dilakukan kapan saja serta mencegah penularan COVID-19 tersebut. 


\section{SIMPULAN}

Berdasarkan hasil penelitian mengenai fenomena dompet digital pada generasi milenial melalui fenomenologi dan interaksi simbolik, simpulan yang didapat diantaranya, pertama yakni memiliki motivasi dalam penggunaan aplikasi OVO yaitu pada shopping dan relaxation dimana Faktor shopping terdiri dari mendapatkan informasi tentang barang dan membeli produk yang diinginkan, sedangkan faktor relaxation terdiri dari memesan sesuatu lebih cepat, merasa lebih nyaman dan aman ketika bertransaksi, tidak merasa khawatir terhadap keuangan dan mempermudah pembayaran.

Simpulan kedua; mind (pikiran), self (diri), society (masyarakat) dari interaksi simbolik. Konsep mind adalah pembentukan proses kegiatan mahasiswa untuk mempertimbangkan menggunakan transaksi nontunai selama pandemi Covid-19 dengan berpijak pada sebuah kebutuhan . Konsep self (diri); berhubungan dengan gambaran diri mahasiwa selama pandemi lebih ke arah perilaku gaya hidup baru menggunakan OVO. Konsep society (masyarakat); mahasiswa UMBandung sebagai bagian dari masyarakat melakukan transaksi pembayaran melalui ovo sebagai bentuk interaksi yang baik untuk mengurangi resiko terinfeksi virus corona. Penelitian selanjutnya dapat fokus pada hubungan perilaku dan adaptasi penggunaan dompet digital di era new normal pandemic Covid-19.

\section{DAFTAR PUSTAKA}

Anonim (2020) PENYEBARAN CEGAH CORONA, DORONG TRANSAKSI NONTUNAI, AYO PAKE QRIS ! Retrieved April 27, 2020, from https://www.jaringanprima.co.id/i d/cegah-penyebaran-virus-coronadorong-transaksi- nontunai-ayopake-qris

Ardianto, E. (2007). Komunikasi Massa Suatu Pengantar. Bandung: Simbiosa Rekatama Media.

Bintarto, E. (2018). Fintech dan Cashless Society: Sebuah Revolusi Mendongkrak Ekonomi Kerakyatan. Call For Essays, 177.

Irawan, I. . (2013). Teori-Teori Sosial dalam Tiga Paradigma: Fakta Sosial, Definisi sosial, dan Perilaku Sosial. Prenada Media Grup.

Moleong, L. J. (2006). Metodelogi Penelitian Kualitatif (revisi ed.). Bandung: PT Remaja Rosdakarya.

Nugroho, O. cahyo. (2015). Interaksi simbolik dalam komunikasi budaya. Aristo, 4(1), 1-18.

Pertiwi, A. . (2018). STUDI FENOMENOLOGI TENTANG KONSEP DIRI WANITA SHOPAHOLIC DI KOTA BANDAR LAMPUNG 
(lampung). Retrieved from https://www.semanticscholar.org/ paper/STUDI-

FENOMENOLOGI-TENTANGKONSEP-DIRI-WANITA-DI-

Pertiwi/ffb1c6fde426877d88cc3b 2650da60471e9741d8

Prama, N. (2020). GoPay Ternyata Jadi Dompet Digital Paling Diminati Generasi $Z$ dan Milenial. Retrieved from https://nextren.grid.id/read/01202 4532/gopay-ternyata-jadi-dompetdigital-paling-diminati-generasi-zdan-milenial?page $=$ all

Rif'ah, S. (2019). FENOMENA CASHLESS SOCIETY DI ERA MILENIAL DALAM PERSPEKTIF. Al-Musthofa: Journal of Sharia Economics, 2(1). Retrieved from http://ejournal.iaitabah.ac.id/index.php/musthofa/ar ticle/view/360

Rosmayanti. (2019). Apa Itu Dompet Digital? Retrieved from https://www.wartaekonomi.co.id/r ead212834/apa-itu-dompetdigital.html

sutriyanto, eko. (2019). 3 Besar Dompet Digital Indonesia Untuk Transaksi Ritel, Transportasi dan Pengiriman Makanan Online. Retrieved from tribunnews.com website:

https://www.tribunnews.com/tech no/2019/07/15/3-besar-dompetdigital-indonesia-untuk-transaksiritel-transportasi-dan-pengirimanmakanan-online

Yuswohady. (2016). Millennial Trends 2016. Retrieved from https://www.yuswohady.com/201 6/01/17/millennial-trends-2016/ 